\title{
Screening of the Enterocin Genes and Antimicrobial Activity against Pathogenic Bacteria in Enterococcus Strains Obtained from Different Origins
}

\author{
Watthana THEPPANGNA ${ }^{1)}$, Toshiyuki MURASE ${ }^{1,2) *}$, Natsumi TOKUMARU ${ }^{1)}$, Hiroki CHIKUMI ${ }^{3)}$, Eiji SHIMIZU ${ }^{3)}$ and \\ Koichi OTSUKI ${ }^{4}$ \\ ${ }^{1)}$ Laboratory of Veterinary Microbiology, Faculty of Agriculture, Tottori University, 4-101 Koyama, Tottori 680-8553, \\ ${ }^{2}$ The Avian Zoonosis Research Center, Faculty of Agriculture, Tottori University, Tottori 680-8553, ${ }^{3)}$ Division of Medical Oncology and \\ Molecular Respirology, Department of Multidisciplinary Internal Medicine, Faculty of Medicine, Tottori University, 36-1 Nishi-cho, \\ Yonago-shi, Tottori-ken 683-8504 and ${ }^{4)}$ Faculty of Technology, Kyoto Sangyo University, Kyoto 605-8555, Japan
}

(Received 3 April 2007/Accepted 21 August 2007)

ABSTRACT. Antimicrobial activities of 139 Enterococcus isolates (48 E. faecium and 91 E. faecalis) obtained from canine feces, boiler meat samples, swine feces, wild waterfowl feces, and human feces were examined against respective bacteria, including Streptococcus pyogenes, Staphylococcus aureus, Bacillus subtilis, Listeria monocytogenes, Salmonella Enteritidis, and Escherichia coli. Bacteriocin (BAC) production assay revealed that the antimicrobial activity against at least one of 6 indicator strains (BAC + phenotype) was found in $51(37 \%)$ isolates $(29 \mathrm{E}$. faecium and $22 \mathrm{E}$. faecalis). Twenty-four of 46 isolates positive for at least one of the enterocin structural genes (entA, entB, ent $L 50 A B$, and $c y l L)$ showed a BAC+ phenotype. The existence of other enterocins or nonenterocin factors was implied because the BAC+ phenotype was detected in a total of 27 Enterococcus isolates that had none of the enterocin genes tested. The antimicrobial activity against Gram-negative strains (Salmonella Enteritidis and E. coli) was detected in the 6 Enterococcus isolates that had either the entA, entB, entL50AB or $c y l L$ genes. Moreover, the proportion of the antimicrobial activity against $L$. monocytogenes among the $c y l L$-positive $E$. faecalis isolates showing beta-hemolysis $(10 / 16)$ was significantly $(\mathrm{p}<0.01)$ higher than among those lacking beta-hemolysis $(2 / 15)$. The results suggested that certain characteristics are likely to be associated with the antimicrobial activity against specific organisms.

KEY WORDS: antimicrobial activity, cytolysin, enterocin, Enterococcus.

J. Vet. Med. Sci. 69(12): 1235-1239, 2007

Enterococci are commensal bacteria of the gastrointestinal tract of mammals and other warm-blooded animals [14, 29, 30]. Enterococcus faecium and E. faecalis are occasionally used in foods for the purpose of the ripening cheeses $[15,24]$ and black olives [13], and also used in probiotic products [17, 33]. However, organisms of the genus Enterococcus, in particular E. faecalis and E. faecium, are of medical relevance because of their increased incidence as a cause of disease, and have also become a significant cause of nosocomial infections $[22,27]$. One factor expressed by many E. faecalis isolates from clinical specimens is cytolysin $[4,18,19]$ which has been associated with virulence of this organism in animal infection models [21]. Although cytolysin confers beta-hemolytic activity, it exhibits a broad target cell range, including both eukaryotic and prokaryotic cells [29], especially Gram-positive organisms [2, 31].

A number of enterocins, bacteriocins produced by enterococci, have been characterized especially in E. faecalis (cytolysin [32], bacteriocin 31 [34], and bacteriocin AS-48 $[16,25]$ ) and E. faecium (enterocin A [1], enterocin B [3], enterocin L50A/L50B [6], enterocin P [5], and enterocin Q [7]). Bacteriocins inhibit the growth of other bacteria that are usually related to bacteriocin-producing organism [20]. The ability to produce bacteriocins may play an important

\footnotetext{
* Correspondence to: MuRASe, T., Laboratory of Veterinary Microbiology, Faculty of Agriculture, Tottori University, 4-101 Koyama, Tottori 680-8553, Japan.

e-mail: murase@muses.tottori-u.ac.jp.
}

physiological role in providing an ecological advantage over others that inhabit the same ecosystem but do not produce these peptides [28]. Thus, it is of interest to determine whether certain genotypic and phenotypic profiles of enterocins are associated with enterococcal isolates from specific origins, such as foods, food animals, and wild animals. In this study, we screened E. faecalis and E. faecium isolates for the enterocin genes described above and antimicrobial activity against representative pathogenic bacteria to determine a possible association between combinations of antimicrobial activity against different bacteria, the enterocin genotypes, species of Enterococcus, and origins of the isolates.

\section{MATERIALS AND METHODS}

Bacterial strains: This study included 139 Enterococcus isolates (48 E. faecium and 91 E. faecalis) from different origins ( 46 boiler meat samples, 44 canine fecal samples, 11 swine fecal samples, 19 wild waterfowl feces, and 19 human fecal samples). The broiler meat samples were from carcasses originally processed in Japan, China, or Brazil from 2000 to 2005 . Canine fecal samples were obtained from animals admitted to a private veterinary hospital and the veterinary teaching hospital of Tottori University in Japan between 2001 and 2004. Swine fecal samples were obtained in October 2005 from different-aged animals on a commercial farm in Japan. Wild waterfowl feces were collected in 
marshes and paddy fields in the western Japan between December 2004 and February 2005, and between November and December 2005 where swans and wild ducks migrate every winter. Enrichment cultures of swab samples from broiler meat and animal fecal samples using heart-infusion broth were plated onto EF agar (Nissui Pharmaceutical Co., Ltd., Tokyo, Japan) and bile esculin azide agar (Difco, Becton Dickinson, Sparks, Md., U.S.A.) and E. faecium or E. faecalis isolates were retained. Identification was carried out by PCR using specific primers for these species [11]. Human isolates were randomly selected from fecal isolates that were recovered from in-patients in Tottori university hospital in 2005. A total of 6 strains of six different bacterial genera, as follows, were used as enterocin production indicators. Streptococcus pyogenes strain 940055 was isolated from a throat swab sample from a human patient. Staphylococcus aureus strain ATCC29213 was purchased from the American Type Culture Collection (ATCC, Manassas, VA, U.S.A.). Listeria monocytogenes strain L98-76P2 was isolated from a pork meat sample. Bacillus subtilis used in this study was isolated from an environmental sample. Salmonella Enteritidis IFO3313 and Escherichia coli IFO3301 were purchased from the Institute of Fermentation, Osaka. S. pyogenes, S. aureus, L. monocytogenes, and Salmonella Enteritidis strains above were used as representative pathogenic organisms.

Detection of enterocin structural genes by PCR: Presence of the entA, entB, entAS-48, bac31, and $c y l L$ genes were detected by a PCR assay as reported previously [33], using the specific primer pairs described by De Vuyst et al. [10]. Because activation of cytolysin is regulated by the $c y l M$, $c y l A$, and $c y l B$ gene products $[12,23]$, the $c y l M[12], c y l A$ [23], and $c y l B$ [23] genes were also screened by PCR. To amplify the $c y l A$, and $c y l B$, a total of 30 cycles of amplification were carried out and each of cycle consisted of $97^{\circ} \mathrm{C}$ denaturation for $1 \mathrm{~min}, 52^{\circ} \mathrm{C}$ annealing for $30 \mathrm{sec}$, and $72^{\circ} \mathrm{C}$ extension for $1 \mathrm{~min}$. PCR amplifications of the cylM was performed by an initial cycle of denaturation at $94^{\circ} \mathrm{C}$ for 2 min, annealing at $56^{\circ} \mathrm{C}$ for $2 \mathrm{~min}$, and elongation at $72^{\circ} \mathrm{C}$ for $2 \mathrm{~min}$, followed by 29 cycles of denaturation at $92^{\circ} \mathrm{C}$ for 15 sec, annealing at $56^{\circ} \mathrm{C}$ for $15 \mathrm{sec}$ and extension for $72^{\circ} \mathrm{C}$ for $15 \mathrm{sec}$. PCR analyses were performed to determine the presence of structural genes of enterocins $50 \mathrm{~A}$ and $50 \mathrm{~B}$ $($ ent $L 50 A / B)$, enterocin $\mathrm{P}($ ent $P)$, and enterocin $\mathrm{Q}($ ent $Q)$ using the specific primer pairs described by [7]. Amplification condition was the same that used for the $c y l A$ and $c y l B$ genes, except that annealing was carried out at $60^{\circ} \mathrm{C}$. PCR products were resolved by electrophoresis on a $1.5 \%$ agarose gel (1X Tris-acetate-EDTA buffer). E. faecium strain GIFU8355 was used as positive control for detection the enterocin A (entA), and enterocin B (entB) genes.

Pulsed-field gel electrophoresis (PFGE): Subtyping of $E$. faecium isolates from swine feces were carried out using PFGE with SmaI-digested chromosomal DNA [26]. PFGE was performed with a $1.0 \%$ agarose gel by using a CHEFDRII apparatus (Bio-Rad Laboratories, Hercules, Calif.) in $0.5 \times$ Tris-borate-EDTA buffer at $14^{\circ} \mathrm{C}$ at $200 \mathrm{~V}$. A linearly ramped switching from 0.5 to $20 \mathrm{sec}$ was applied for $20 \mathrm{hr}$.

Enterocin and beta-hemolysin assay: Enterocin detection was carried out by the method previously described by Del Campo et al. [9]. The antimicrobial activity due to enterocins in enterococcal isolates from different origins was visually detected by observing clear inhibition zones around the producer strain on the agar plate seeded with each of the indicator strains. Those strains in which antimicrobial activity were observed, were designated Bac + . This assay does not discriminate between single and multiple enterocin production. Beta-hemolytic activity was examined using Columbia blood agar base (Becton, Dickinson and Co., Sparks, MD) plates supplemented with 5\% (v/v) of either sheep blood or horse blood. The presence of a clear zone of hemolysis around the colonies in both the blood plates was referred as a positive.

Statistical analysis: Statistical analysis of the proportion of antilisterial activity among the $c y l L M B A$ harboring $E$. faecalis isolates positive or negative for beta-hemolysis was done by the Fisher's exact test, and statistical significance was determined at $\mathrm{p}<0.05$.

\section{RESULTS}

The enterocin assay revealed that antimicrobial activity against at least 1 of 6 indicator strains (BAC + phenotype) was shown in 51 of the 139 Enterococcus isolates tested (Table 1). Of 48 E. faecium, $29(60 \%)$ were BAC+, whereas this phenotype was detected in only 22 of 91 (24\%) E. faecalis isolates. Eight of $9 \mathrm{E}$. faecium isolates obtained from pig feces were BAC+ phenotype. Because these isolates were obtained from different-aged pigs in the same farm, the possible relationships among the $\mathrm{BAC}+E$. faecium were investigated using PFGE. SmaI-digested PFGE patterns of the 8 E. faecium isolates showed multiple band differences (data not shown), indicating that these isolates were genetically unrelated.

One or more enterocin structural genes (cylL, entA, entB, and ent $50 A / B)$ were detected in $46(33 \%)$ Enterococcus isolates (12 E. faecium and 34 E. faecalis) (Table 1). All the $c y l L$-positive isolates had the $c y l M$, $c y l B$, and $c y l A$ genes. The $c y l$ genes were mainly detected in E. faecalis strains, while the ent $A$ and $e n t B$ genes were detected in strains of both E. faecium and E. faecalis. Of 33 Enterococcus isolates (31 E. faecalis and 2 E. faecium) that had the cyl genes, 19 E. faecalis strains did not show BAC+. All the $9 E$. faecium strains positive for the entA or ent $B$ genes were $\mathrm{BAC}+$, whereas all the 3 E. faecalis strains with these genes had no antimicrobial activities. None of Enterococcus isolates studied had the entP, entQ, bac31, and entAS-48 genes. Of 93 Enterococcus strains negative for the enterocin genes investigated, 27 strains (10 E. faecalis and 17 E. faecium) were found to be BAC+.

The results of antimicrobial activities against different indicator strains for $51 \mathrm{BAC}+$ Enterococcus isolates are shown in Table 2. Various combinations of antimicrobial activities against 6 indicator strains were found in Entero- 
Table 1. Antimicrobial activity and enterocin genes detected in Enterococcus isolates from different origins

\begin{tabular}{|c|c|c|c|c|c|c|c|}
\hline \multirow[b]{2}{*}{ Species } & \multirow[b]{2}{*}{$\begin{array}{l}\text { BAC+ } \\
\text { phenotype }\end{array}$} & \multirow[b]{2}{*}{$\begin{array}{l}\text { Enterocin } \\
\text { gene }\end{array}$} & \multicolumn{5}{|c|}{ Isolates from: } \\
\hline & & & $\begin{array}{c}\text { Broiler } \\
\text { meat }\end{array}$ & $\begin{array}{l}\text { Canine } \\
\text { feces }\end{array}$ & $\begin{array}{l}\text { Swine } \\
\text { feces }\end{array}$ & $\begin{array}{l}\text { Wild waterfowl } \\
\text { feces }\end{array}$ & Human \\
\hline \multirow[t]{6}{*}{ E. faecium } & BAC + & cylLMBA & & 2 & & & \\
\hline & & ent $A+e n t B$ & & 1 & & 1 & \\
\hline & & entA & & 4 & 2 & & 1 \\
\hline & & ent $L 50 A B$ & & & 1 & & \\
\hline & & None & 7 & 4 & 5 & 1 & \\
\hline & Non-BAC+ & None & 10 & 7 & 1 & 1 & \\
\hline \multirow[t]{6}{*}{ E. faecalis } & $\mathrm{BAC}+$ & cylLMBA & & 7 & & 1 & 4 \\
\hline & & None & 6 & 2 & & 2 & \\
\hline & Non-BAC+ & cylLMBA & 3 & 9 & & 3 & 4 \\
\hline & & ent $A+e n t B$ & 1 & 1 & & & \\
\hline & & entA & & 1 & & & \\
\hline & & None & 19 & 6 & 2 & 10 & 10 \\
\hline
\end{tabular}

Table 2. Antimicrobial activity against a series of 6 indicator strains detected in $\mathrm{BAC}+$ isolates

\begin{tabular}{|c|c|c|c|c|c|c|}
\hline \multirow[b]{2}{*}{ Indicator strain } & \multicolumn{6}{|c|}{ E. faecium (left) and E. faecalis (right) from: } \\
\hline & $\begin{array}{r}\text { Broi } \\
\text { me }\end{array}$ & & $\begin{array}{l}\text { Canine } \\
\text { feces }\end{array}$ & $\begin{array}{l}\text { Swine } \\
\text { feces }\end{array}$ & $\begin{array}{l}\text { Wild waterfowl } \\
\text { feces }\end{array}$ & Human \\
\hline S. pyogenes & $7 / 7^{\mathrm{a})}$ & $0 / 6$ & $5 / 11 \quad 1 / 9$ & $5 / 8 \quad 0 / 0$ & $1 / 2 \quad 0 / 3$ & $0 / 1 \quad 2 / 4$ \\
\hline S. aureus & $7 / 7$ & $0 / 6$ & $8 / 11 \quad 1 / 9$ & $8 / 8 \quad 0 / 0$ & $1 / 2 \quad 0 / 3$ & $0 / 1 \quad 0 / 4$ \\
\hline L. monocytogenes & $0 / 7$ & $0 / 6$ & $4 / 11 \quad 8 / 9$ & $1 / 8 \quad 0 / 0$ & $1 / 2 \quad 3 / 3$ & $1 / 1 \quad 4 / 4$ \\
\hline B. subtilis & $0 / 7$ & $5 / 6$ & $0 / 11 \quad 4 / 9$ & $1 / 8 \quad 0 / 0$ & $0 / 2 \quad 1 / 3$ & $0 / 1 \quad 3 / 4$ \\
\hline S. Enteritidis & $0 / 7$ & $0 / 6$ & $0 / 11 \quad 1 / 9$ & $\begin{array}{ll}3 / 8 & 0 / 0\end{array}$ & $1 / 2 \quad 0 / 3$ & $0 / 1 \quad 1 / 4$ \\
\hline E. coli & $0 / 7$ & $0 / 6$ & $0 / 11 \quad 1 / 9$ & $1 / 8 \quad 0 / 0$ & $1 / 2 \quad 0 / 3$ & $0 / 1 \quad 0 / 4$ \\
\hline
\end{tabular}

a) Number of isolates with antimicrobial activity against each of the indicator strains/ number of $\mathrm{BAC}+$ isolates.

Table 3. The presence of beta-hemolytic activity and antilisterial activity in the cylLMBA-positive $E$. faecalis isolates from different origins

\begin{tabular}{lllccc}
\hline & & \multicolumn{4}{c}{ cylLMBA-positive isolates from: } \\
\cline { 3 - 6 } $\begin{array}{l}\text { Beta- } \\
\text { hemolysis }\end{array}$ & $\begin{array}{l}\text { Antilisterial } \\
\text { activity }\end{array}$ & $\begin{array}{c}\text { Broiler } \\
\text { meat }\end{array}$ & $\begin{array}{c}\text { Canine } \\
\text { feces }\end{array}$ & $\begin{array}{c}\text { Wild waterfowl } \\
\text { feces }\end{array}$ & Human \\
\hline Yes & Yes & & 7 & 1 & 2 \\
Yes & No & & 2 & 3 & 1 \\
No & Yes & & & & 2 \\
No & No & 3 & 7 & & 3 \\
\hline
\end{tabular}

coccus isolates studied. One E. faecalis isolate with the $c y l$ genes obtained from a dog and one E. faecium with the ent $L 50 A / B$ genes obtained from a pig showed antimicrobial activities against all 6 indicator strains. Six isolates that showed antimicrobial activities against Gram-negative bacteria (E. coli and/or Salmonella Enteritidis) had one of the entA, entB, cylLMBA, and entL50A/B genes. Enterococcus isolates obtained from broiler meat showed antimicrobial activities only against the Gram-positive indicator strains used. The antimicrobial activity against $L$. monocytogenes was found in a high proportion of $E$. faecalis isolates obtained from humans (4/4), dogs (8/9), and wild waterfowl feces $(3 / 3)$. Of the $18 \mathrm{E}$. faecalis isolates positive for the antilisterial activity, 12 isolates had the $c y l$ genes (Table 3). Remaining 6 isolates ( 2 from wild waterfowl feces, 3 from boiler meat and 1 from dog) were negative for all enterocin genes tested. Beta-hemolysis was found in 16 E. faecalis isolates and $2 \mathrm{E}$. faecium isolates with the cyl genes, although 15 of the $31 \mathrm{E}$. faecalis isolates positive for these genes did not show beta-hemolysis (Table 3 ). The incidence of antimicrobial activity against $L$. monocytogenes found in the $c y l$ genes-positive E. faecalis isolates showing betahemolytic activity $(10 / 16)$ was significantly $(\mathrm{P}<0.01)$ higher than that found in the isolates without beta-hemolytic activity $(2 / 15)$. Of 7 E. faecium isolates positive for antilisterial activity (Table 2), 1 isolate from dog feces was positive for the $c y l$ genes, 1 and 3 isolates from a human and dog feces, respectively, had the ent $A$, and 1 isolate from swine feces had the entL5OAB gene. 


\section{DISCUSSION}

Almost $37 \%$ of Enterococcus isolates used in this study showed BAC + activity. The incidence of BAC + isolates was higher among $E$. faecium $(60 \%)$ than among $E$. faecalis (24\%) isolates. According to Poeta et al. [28], 49\% of $E$. faecium and $37 \%$ of E. faecalis isolates of different wild animal origin showed antimicrobial activity against at least one of the tested indicator strains. On the contrary, Del Campo et al. [9] found a higher proportion of BAC+ isolates among E. faecalis $(80.6 \%)$ than among E. faecium $(21.6 \%)$ isolates obtained from human clinical and fecal samples, sewage, and chicken samples. Similarly, De Vuyst et al. [10] reported that bacteriocin production was found among $58.7 \%$ and $68.3 \%$ of E. faecium and E. faecalis strains, respectively, of different origins, including food, feed, animals, and clinical and nonclinical human isolates. Inconsistency of the $\mathrm{BAC}+$ phenotype incidence among these species may be partly due to difference in indicator strains used. Moreover, environmental factors, such as feeds, conditions found in the gastrointestinal tract, and the balance of organisms in the intestinal flora are likely to affect the presence and persistence of enterococci because BAC + phenotype was found in 8 of 9 genetically unrelated $E$. faecium isolates in our study that were obtained from pigs kept in a single farm.

The results of the antimicrobial activity and the PCR results imply the existence of other enterocin genes that were not tested in this study. None of enterocin genes tested were found in all of the 7 E. faecium and 6 E. faecalis with $\mathrm{BAC}+$ phenotype that were obtained from broiler meat. Five of the 8 isolates with $\mathrm{BAC}+$ phenotype (exclusively against Gram-positive indicator strains) from pig feces had no detectable enterocin genes. Nucleotide substitutions in the enterocin genes may prevented PCR amplification with the selected primers used in this study because possible sequence divergence of the $c y l$ genes were suggested [29]. Except for the above observation, similar tendencies in distribution of enterocin genes tested were not found among enterococcal isolates of different origins.

Marked variations of inhibitory spectra were shown among Enterococcus isolates with identical enterocin genotypes. Nevertheless, antimicrobial activities against Gramnegative bacteria (E. coli and Salmonella Enteritidis) were found in 6 Enterococcus isolates that had one of the cylL$M B A$, ent $A$, and ent $L 5 O A B$ genes. We have previously demonstrated [33] that the inhibitory activity against Salmonella Enteritidis was found in one E. gallinarum strain that was negative for all of the above genes [33]. Therefore, association of other enterocins or nonenterocin factors with the inhibitory effect against Salmonella Enteritidis in this study can not be excluded. Enterocin A has been reported to show antimicrobial activity against L. monocytogenes [1], although in the current study, no antilisterial activity was detected in more than half (5/9) of E. faecium and all of the 3 E. faecalis isolates possessing the entA gene. Other researchers have noted that phenotypic testing revealed the existence of apparently silent genes [10, 12].

Possible correlation between beta-hemolytic strains of $E$. faecalis positive for the $c y l L M B A$ genes and antimicrobial activities against $L$. monocytogenes was demonstrated in the present study. The incidence of antilisterial activity among the $c y l$ genes-positive isolates with beta-hemolytic activity was significantly higher than among beta-hemolysis negative isolates. In this study, beta-hemolytic activity was exclusively shown in the strains with the $c y l L$ gene. Interestingly, cytolysin is not considered to be active against $L$. monocytogenes [8]. Thus, it remains to be determined whether beta-hemolysis and antilisterial activity are actually mediated by the same agent, although the beta-hemolytic characteristic may be intimately associated with the production of unknown agents possessing antilisterial activity, even new enterocins.

In summary, observations in our study suggest that the antimicrobial activity may be associated with other enterocin genes that was not studied or nonenterocin factors. Investigating the correlation between a certain characteristic and antimicrobial activity against specific organism is likely to offer a first step in identifying novel agents exhibiting such activity.

ACKNOWLEDGMENTS. The authors are grateful to Dr. Peter S. Holt for reviewing this manuscript. S. pyogenes strain 940055 was kindly provided from Kanagawa Prefectural Public Health Laboratory. L. monocytogenes strain L98-76P2 was kindly provided by Professor R. Hondo, Nippon Veterinary and Life Science University.

\section{REFERENCES}

1. Aymerich, T., Holo, H., Havarstein, L. S., Hugas, M., Garriga, M. and Nes, I. F. 1996. Biochemical and genetic characterization of enterocin A from Enterococcus faecium, a new antilisterial bacteriocin in the pediocin family of bacteriocins. Appl. Environ. Microbiol. 62: 1676-1682.

2. Brock, T. D. and Davie, J. M. 1963. Probable identity of a group D hemolysin with a bacteriocine. J. Bacteriol. 86: 708712 .

3. Casaus, P., Nilsen, T., Cintas, L. M., Nes, I. F., Hernandez, P. E. and Holo, H. 1997. Enterocin B, a new bacteriocin from Enterococcus faecium T136 which can act synergistically with enterocin A. Microbiology 143: 2287-2294.

4. Chow, J. W., Thal, L. A., Perri, M. B., Vazquez, J. A., Donabedian, S. M., Clewell, D. B. and Zervos, M. J. 1993. Plasmidassociated hemolysin and aggregation substance production contribute to virulence in experimental enterococcal endocarditis. Antimicrob. Agents Chemother. 37: 2474-2477.

5. Cintas, L. M., Casaus, P., Havarstein, L. S., Hernandez, P. E. and Nes, I. F. 1997. Biochemical and genetic characterization of enterocin P, a novel sec-dependent bacteriocin from Enterococcus faecium $\mathrm{P} 13$ with a broad antimicrobial spectrum. Appl. Environ. Microbiol. 63: 4321-4330.

6. Cintas, L. M., Casaus, P., Holo, H., Hernandez, P. E., Nes, I. F. and Havarstein, L. S. 1998. Enterocins L50A and L50B, two novel bacteriocins from Enterococcus faecium L50, are related to staphylococcal hemolysins. J. Bacteriol. 180: 1988-1994.

7. Cintas, L. M., Casaus, P., Herranz, C., Havarstein, L. S., Holo, 
H., Hernandez, P. E. and Nes, I. F. 2000. Biochemical and genetic evidence that Enterococcus faecium L50 produces enterocins L50A and L50B, the sec-dependent enterocin P, and a novel bacteriocin secreted without an $\mathrm{N}$-terminal extension termed enterocin Q. J. Bacteriol. 182: 6806-6814.

8. Cintas, L. M., Casaus, M. P., Herranz, C., Nes, I. F. and Hernandez, P. E. 2001. Review: bacteriocins of lactic acid bacteria. Int. J. Food Sci. Technol. 7: 281-305.

9. Del Campo, R., Tenorio, C., Jimenez-Diaz, R., Rubio, C., Gomez-Lus, R., Baquero, F. and Torres, C. 2001. Bacteriocin production in vancomycin-resistant and vancomycin-susceptible Enterococcus isolates of different origins. Antimicrob. Agents Chemother. 45: 905-912.

10. De Vuyst, L., Foulquie Moreno, M. R. and Revets, H. 2003. Screening for enterocins and detection of hemolysin and vancomycin resistance in enterococci of different origins. Int. J. Food Microbiol. 84: 299-318.

11. Dutka-Malen, S., Evers, S. and Courvalin, P. 1995. Detection of glycopeptides resistance genotypes and identification to the species level of clinically relevant enterococci by PCR. J. Clin. Microbiol. 33: 24-27 (Erratum, 33, 1434).

12. Eaton, T. J. and Gasson, M. J. 2001. Molecular screening of Enterococcus virulence determinants and potential for genetic exchange between food and medical isolates. Appl. Environ. Microbiol. 67: 1628-1635.

13. Franz, C. M., Schillinger, U. and Hozapfel, W. H. 1996. Production and characterization of enterocin 900 , a bacteriocin produced by Enterococcus faecium BFE900 from black olives. Int. J. Food Microbiol. 29: 255-270.

14. Gilmore, M. S. and Ferretti, J. J. 2003. Microbiology. The thin line between gut commensal and pathogen. Science 299: 19992002.

15. Giraffa, G. 1995. Enterococcal bacteriocins: their potential as anti-Listeria factors in dairy technology. Food Microbiol. 12: 301-307.

16. Gonzalez, C., Langdon, G. M., Bruix, M., Galvez, A., Valdivia, E., Maqueda, M. and Rico, M. 2000. Bacteriocin AS48, a microbial cyclic polypeptide structurally and functionally related to mammalian NK-lysin. Proc. Natl. Acad. Sci. U.S.A. 97: 11221-11226.

17. Holzapfel. W. H., Haberer, P., Snel, J., Schillinger, U. and Huis in 't Veld, J. H. 1998. Overview of gut flora and probiotics. Int. J. Food Microbiol. 41: 85-101.

18. Huycke, M. M., Spiegel, C. A. and Gilmore, M. S. 1991. Bacteremia caused by hemolytic, high-level gentamycin-resistant Enterococcus faecalis. Antimicrob. Agents Chemother. 35 : $1626-1634$.

19. Ike, Y., Hashimoto, H. and Clewell, D. B. 1987. High incidence of hemolysin production by Enterococcus (Streptococcus) faecalis strains associated with human parenteral infections. J. Clin. Microbiol. 25: 1524-1528.

20. Jack, R. W., Tagg, J. R. and Ray, B. 1995. Bacteriocins of Gram-positive bacteria. Microbiol. Rev. 59: 171-200.
21. Jett, B. D., Jensen, H. G., Nordquist, R. E. and Gilmore, M. S. 1992. Contribution of the pAD1-encoded cytolysin to the severity of experimental Enterococcus faecalis endophthalmitis. Infect. Immun. 60: 2445-2452.

22. Jett, B. D., Huycke, M. M. and Gilmore, M. S. 1994. Virulence of enterococci. Clin. Microbiol. Rev. 7: 462-478.

23. Khan, S. A., Nawaz, M. S., Khan, A. A., Hopper, S. L., Jones, R. A. and Cerniglia, C. E. 2005. Molecular characterization of multidrug-resistant Enterococcus spp. From poultry and dairy farms: detection of virulence and vancomycin resistance gene markers by PCR. Mol. Cell. Probes. 19: 27-34.

24. Litopoulou-Tzanetaki, E. and Tzanetakis, N. 1992. Microbiology of white brined cheese made from raw goat milk. Food Microbiol. 9: 13-19.

25. Maqueda, M., Galvez, A., Martinez-Bueno, M. and Valdivia, E. 1998. Widespread production of AS-48 like bacteriocins in strains of Enterococcus faecalis. Mol. Microbiol. 29: 13181319.

26. Murase, T., Mito, Y., Otsuki, R. and Yamai, S. 2002. Nucleotide substitutions in vanC-2 gene of Enterococcus casselifla$v u s$ isolates obtained from chickens. Epidemiol. Infect. 129: 421-424.

27. Murray, B. E. 2000. Vancomycin-resistant enterococcal infections. New Engl. J. Med. 342: 710-721.

28. Poeta, P., Costa, D., Rojo-Bezares, B., Zarazaga, M., Klibi, N., Rodrigues, J. and Torres, C. 2006. Detection of antimicrobial activities and bacteriocin structural genes in faecal enterococci of wild animals. Microbiol. Res. 162: 257-263.

29. Semedo, T., Almeid Santos, M., Martins, P., Silva Lopes, M. F., Figueiredo Marques, J. J., Tenreiro, R. and Barreto Crespo, M. T. 2003. Comparative study using type strains and clinical and food isolates to examine hemolytic activity and occurrence of the cyl operon in enterococci. J. Clin. Microbiol. 41: 25692576.

30. Shankar, N., Coburn, P., Pillar, C., Haas, W. and Gilmore, M. 2004. Enterococcal cytolysin: activities and association with other virulence traits in a pathogenicity island. Int. J. Med. Microbiol. 293: 609-618.

31. Stark, J. M. 1960. Antibiotic activity of haemolytic enterococci. Lancet i: 733-734.

32. Tanimoto, K., Florence, Y. and Clewell, D. B. 1993. Characterization of the traC determinant of the E. faecalis hemolysinbacteriocin plasmid pAD1: binding to sex pheromone. J. Bacteriol. 175: 5260-5264.

33. Theppangna, W., Otsuki, K. and Murase, T. 2006. Inhibitory effect of Enterococcus strains obtained from a probiotic product on in vitro growth of Salmonella enterica serovar Enteritidis strain IFO3313. J. Food Prot. 69: 2258-2262.

34. Tomita, H., Fujimoto, S., Tanimoto, K. and Ike, Y. 1996. Cloning and genetic sequence analysis of the bacteriocin 31 determinant encoded on the Enterococcus faecalis pheromoneresponsive conjugative plasmid pPD1. J. Bacteriol. 79: 78437855 . 